\title{
Nanobilim ve Nanoteknolojinin TÜBİTAK Popüler Bilim Dergilerine Yansımalari*
}

Şeyma Çalık Bostanc1 a

Ayşe Boyraz ${ }^{b}$

Tuba Şenel Zor ${ }^{\mathrm{C}}$

Erhan Zord

Oktay Aslan $\mathrm{e}^{\mathrm{a}}$

(a) Yüksek Lisans Öğrencisi, Necmettin Erbakan Üniversitesi, ORCID: 0000-0002-3640-5195; (b) Yüksek Lisans Öğrencisi, Necmettin Erbakan Üniversitesi, ORCID: 0000-0002-8573-6935; (c) Arş.Gör, Gazi Üniversitesi, ORCID: 0000-0002-20930825; (d) Doç.Dr., Necmettin Erbakan Üniversitesi, ORCID: 0000-0002-2325-6354; (e) Doç.Dr., Necmettin Erbakan Üniversitesi, ORCID: 0000-0001-7938-1413

\begin{tabular}{|c|c|}
\hline ÖZET & MAKALE BİLGİSİ \\
\hline 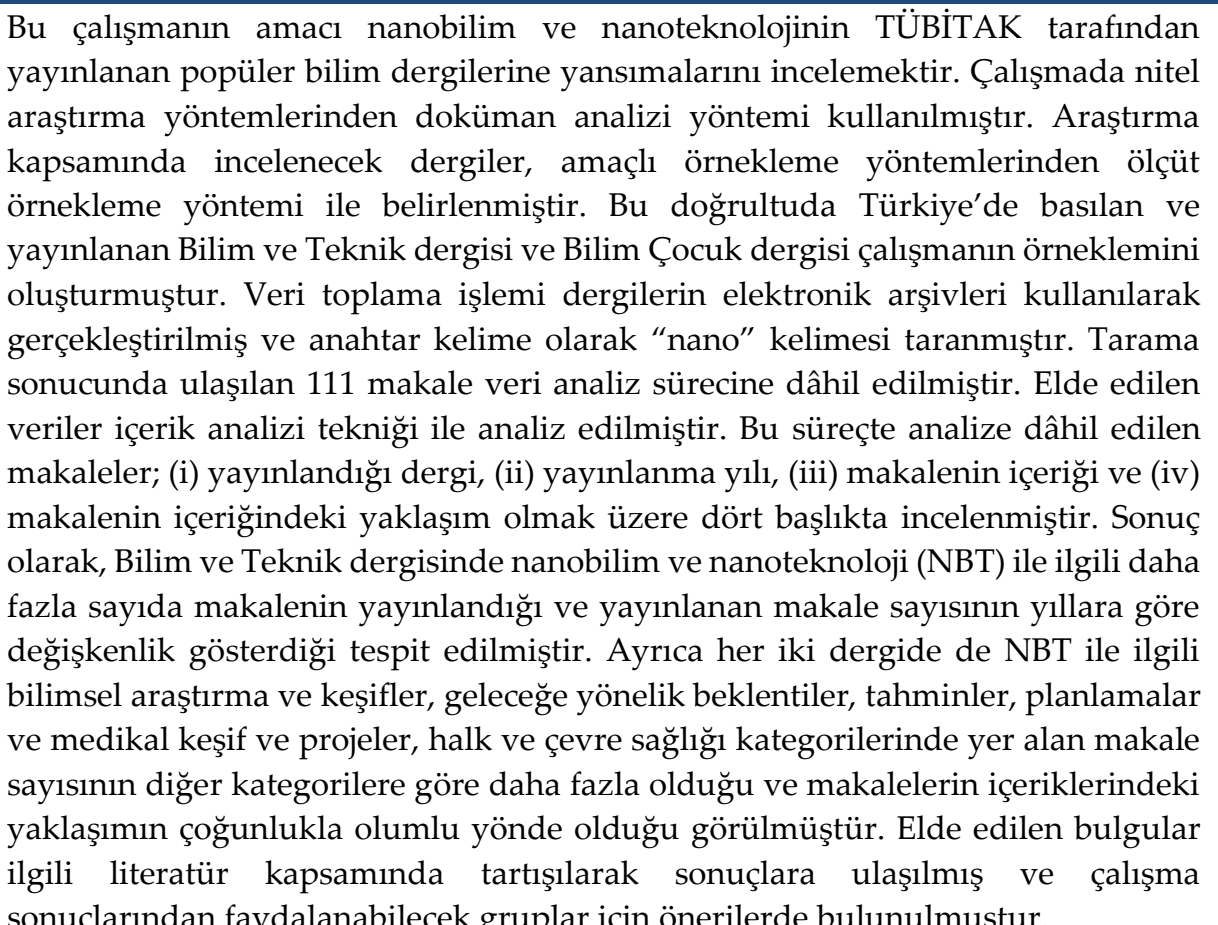 & $\begin{array}{l}\text { Anahtar Kelimeler } \\
\text { Popüler Bilim, } \\
\text { Dergi, } \\
\text { Nanobilim, } \\
\text { Nanoteknoloji }\end{array}$ \\
\hline
\end{tabular}

Atıf Bilgisi: Çalık Bostancı, Ş., Boyraz, A., Şenel Zor, T., Zor, E. ve Aslan, O. (2021). Nanobilim ve nanoteknolojinin TÜBİTAK popüler bilim dergilerine yansımaları. Uluslararası Türk Eğitim Bilimleri Dergisi, 10 (17), 90-113.

Sorumlu yazar: Şeyma Çalık Bostancı, e-posta: calikseyma95@gmail.com

"Bu çalışma VIIth International Eurasian Educational Research Congress (EJER) kongresinde sözlü bildiri olarak sunulmuştur. Doküman analizi yöntemine göre yürütülen bu çalışma için etik kurul belgesi gerekmemektedir. 


\title{
Reflections of Nanoscience and Nanotechnology in TUBITAK Popular Science Magazines*
}

\author{
Şeyma Çalık Bostanci ${ }^{\mathrm{a}}$ \\ Ayşe Boyraz ${ }^{b}$ \\ Tuba Şenel Zor ${ }^{\mathrm{C}}$ \\ Erhan Zord \\ Oktay Aslan ${ }^{\mathrm{e}}$
}

(a) Graduate Student, Necmettin Erbakan University, ORCID: 0000-0002-3640-5195; (b) Graduate Student, Necmettin Erbakan University, ORCID: 0000-0002-8573-6935; (c) Ress.Assist., Gazi University, ORCID: 0000-0002-2093-0825; (d) Assoc.Prof.Dr., Necmettin Erbakan University, ORCID: 0000-0002-2325-6354; (e) Assoc.Prof.Dr., Necmettin Erbakan University, ORCID: 0000-0001-7938-1413

\begin{tabular}{|c|c|}
\hline & \\
\hline $\begin{array}{l}\text { This study aims to examine the reflections of nanoscience and nanotechnology in } \\
\text { popular science magazines published by TUBITAK. Document analysis method, } \\
\text { which is one of the qualitative research methods, was used in the study. Magazines } \\
\text { were determined by criterion sampling method. In this respect, Bilim ve Teknik } \\
\text { magazine and Bilim Çocuk magazine published in Turkey form the sample of the } \\
\text { study. Data collection was carried out using electronic archives of magazines and the } \\
\text { word "nano" was searched as the keyword. After searching, } 111 \text { articles were included } \\
\text { in the data analysis process. The obtained data were analyzed by using the content } \\
\text { analysis technique. Articles included in the analysis in this process were examined } \\
\text { under four titles; (i) the magazines in which it was published, (ii) the year of } \\
\text { publication, (iii) the content of the article, and (iv) the approach in the content of the } \\
\text { article. As a result, it was determined that more articles related to nanoscience and } \\
\text { nanotechnology (NST) were published in Bilim Teknik, and the number of articles } \\
\text { published varies by year. Also, the number of articles in the categories of scientific } \\
\text { research and discoveries, expectations-forecasts-planning for the future and medical } \\
\text { discovery and projects, environment and public health on NST was higher than the } \\
\text { others, and the approach in the content of the articles was mostly positive in both } \\
\text { magazines. The findings were discussed within the scope of the relevant literature, } \\
\text { and suggestions were made for the groups that could benefit from the study results. }\end{array}$ & $\begin{array}{l}\text { Key Words } \\
\text { Popular Science, } \\
\text { Magazine, } \\
\text { Nanoscience, } \\
\text { Nanotechnology }\end{array}$ \\
\hline
\end{tabular}

To cite this article: Çalık Bostancı, Ş., Boyraz, A., Şenel Zor, T., Zor, E. \& Aslan, O. (2021). Reflections of Nanoscience and Nanotechnology in TUBITAK Popular Science Magazines. International Journal of Turkish Educational Sciences, 10 (17), 90-113.

Corresponding Author: Şeyma Çalık Bostancı, e-mail: calikseyma95@gmail.com

\footnotetext{
* This study was presented as an oral presentation at the VIIth International Eurasian Educational Research Congress (EJER). Ethics committee certificate is not required for this study, which was carried out according to the document analysis method.
} 


\section{Giriş}

İnsanlar varoluşundan beri evrende gerçekleşen olayları anlama, evrenin sırlarını çözme ve doğayı kendi kontrolleri altına alarak rahat ve güvenli bir yaşam sürmek istemiş ve bu gereksinimleri bilimin doğuşu için bir zemin hazırlamıştır (Utma, 2015). Günümüzde ise toplumlar bilim ve teknolojide yaşanan hızlı gelişmelere bağlı olarak bilgiye ve bilgi edinimine çok daha fazla önem veren bir duruma gelmiştir. Bu durumun doğal bir sonucu olarak bilgi toplumunu oluşturmakta olan kişilerin bilgilere ulaşmaları, bilgileri yorumlayabilmeleri ve ihtiyaç halinde bu bilgileri kullanabilecek becerilere sahip olmaları önem taşımaktadır. Çünkü sahip olunan bu yetkinlik ve beceriler kişileri bilimle karşı karşıya getirmektedir (Ucer, 2019). Bilim ve teknoloji, zamanla tüm toplumların yaşamına daha fazla dâhil olmakta, artarak devam eden teknolojik gelişmeler ve bunların insanlara yansımaları bilimi insan yaşamında önemli bir noktaya taşımakta ve bu etkileşim insanları az ya da çok bilimle ilgilenir hale getirmektedir. İnsanların bilimle ilgilenme nedenleri farklı olsa da birçok toplumun bilime olan ilgilerinin ve bilimden beklentilerinin giderek daha fazla arttığı bilinmektedir (Güner ve Çitçi, 2010).

21. yüzyılın yeni devrimi olarak kabul edilen nanobilim ve nanoteknoloji modern araştırmaların ön saflarında yer almaktadır (Sebastian ve Gimenez, 2016). Nanobilim; maddenin nano ölçekte manipülasyonu ve kontrolü sonucunda meydana gelen olayların bilimsel olarak incelenmesi ve anlaşılması (Baalousha, How, Valsami-Jones ve Lead, 2014) olarak tanımlanırken, nanoteknoloji; ortaya çıkan nanoyapıların daha büyük sistemlere entegrasyonunun yanı sıra tek tek atomlardan veya moleküllerden mikronaltı boyutlara kadar değişen ölçeklerde kimyasal, fiziksel ve biyolojik sistemlerin nano üretimi ve uygulamasını kapsayan alanı ifade etmektedir (Bhushan, 2015).

Nanoteknoloji, yeni özellikleri keşfetmek ve malzemelerin mevcut özelliklerini yeni cihazlarda ve sistemlerde kullanmak üzere optimize etmek için mükemmel bir firsat sunar (Soltani, Tabatabaeian, Hanafizadeh ve Soofi, 2011). Bu teknoloji maddelere daha önce görülmemiş ve çok farklı yeni özellikler kazandırması sayesinde günümüzün en önemli teknolojilerinden biri haline gelmiştir (Güzeloğlu, 2015). Nanoteknoloji alanında yapılan araştırmalar ve yenilikler, tıp ve sağlık hizmetleri, bilgi teknolojisi, nano malzemeler ve nano üretim, nanoelektronik, enerji, ulusal güvenlik, tarım, tekstil ve kozmetik gibi çeşitli sektörlere katkıda bulunmaktadır (Bhushan, 2010; Erkoç, 2012; Singh, 2017). Bu alanlarda geleceğe yönelik yapılan araştırmaların devrim niteliğinde gelişmeler yaratacağ 1 düşünülmekte ve nanoteknolojiden, sıklıkla geleceğin sanayi devrimi olarak bahsedilmektedir (Aktürk, 2013; Bhushan, 2010; Lewenstein, Gorss ve Radin, 2009).

Tüm bu olumlu yönleri ile birlikte NBT bilim iletişimi ve toplumun bilim anlayışı ile ilgilenen bilim insanlarının ve halkın dikkatini çeken tartışmalı bir bilimdir (Stephens, 2005). İlerleyen zamanlarda NBT'nin etkilerinin topluma ve günlük yaşamımıza daha fazla yansıması durumunda, tüm bireylerin bu konulara yönelik tartışmalarla karşı karşıya kalma durumu söz konusudur (Hingant ve Albe, 2010). Nanoteknolojiyi çevreleyen tartışmalar toplumun nanoteknolojiye olan güvenini ciddi şekilde etkileyebileceğinden dolayı başarılı bilim iletişimi önemlidir. Çünkü iletişim yanlış bir şekilde yapıldığında, halkı yatıştırmaya yönelik bilgiler endişe uyandırabilecek hale gelebilir ve tepkilere neden olabilir (Boholm ve Larsson, 2019). 
Demokratik toplumlarda halk, araştırma alanlarındaki gelişmeler hakkında bilgi edinme ve akademi ve araştırma enstitülerinde neler yapıldığının sonuçlarını anlama hakkına sahiptir (Pramling ve Säljö, 2007). Toplumun bilgilenebilme süreci, bilimsel bilgi ve düşüncenin yaygınlaşması ve toplumun bilimi takip edebilecek kadar konuya dâhil edilmesi için gereklidir (Kılıç, 2009). İnsanların merak ettiği bilimsel içerikli konuları anlamalarına yardımcı olma hususunda bilimi popülerleştirmek oldukça faydalıdır ve bu durum insanların bilimle tanışmasına yardımcı olur (Akoğlu, 2005). Hayatımızda "Popüler bilim" ya da "bilimi popülerleştirmek" kavramları olmasaydı, birçok insan için bilim sadece erişilmesi ve anlaşılması zor bir olgu olarak kalırdı (Türkiye Bilimsel ve Teknolojik Araştırma Kurumu [TÜBİTAK], t.y.). 20. yüzyılda yayınlanan dergi ve gazetelerin halkın bilimsel okuryazarlığını artırma ve bilimi popülerleştirme konusunda oldukça önemli bir role sahip olduğu bilinmektedir (Babaii, Atai ve Saidi, 2017).

Bulunduğu dönem içerisinde ön planda olan ve toplumun ilgiyle takip ettiği konular "popüler bilim" olarak adlandırılarak geniş bir kitleye hitap etmiştir (Eroğlu ve Sağlam, 2019). Popüler bilim, bilimle uğraşmamış olan insanların anlayamayacağı konuları, onların anlayıp faydalanabilecekleri bir forma dönüştürerek insanlara sunar. Popüler bilim, teknik terimlerin oldukça sık kullanıldığı karmaşık ve ağır bilim dilini, halkın kullandığı dile yakın bir hale çevirmekte ve böylece bilim ve teknolojiyle ilgili güncel konuları halk da takip edebilir duruma gelmektedir. Halkın bilimsel olaylardan haberdar olmasını amaçlayan yayıncılığa da popüler bilim yayıncılığı adı verilmektedir (Özsevgeç, Eroğlu ve Öztürk Köroğlu, 2017). Yani popüler bilim yayıncılığında yayımlanan metinler akademik makalelerden ve özellikle araştırma makalelerinden daha basit bir şekilde sunulmaktadır (Parkinson ve Adendorff, 2004). Bu noktada popüler bilim dergileri, toplumu bilim dünyasına ulaştıran bir köprü görevi görmekte (TÜBİTAK, t.y.) ve bilim iletişiminin sağlanmasında vazgeçilmez araçlar arasında bulunmaktadır (Pramling ve Säljö, 2007). Bu dergiler bir yandan potansiyel olarak ilginç uygulamalar konusunda halkı bilinçlendirirken diğer bir yandan da güncel araştırmalar hakkında bilimsel toplulukları bilinçlendirmektedir (Tseronis, 2018).

TÜBİTAK, ülkemizin rekabet gücünü ve refahını artırmak ve sürekliliğini sağlamak üzere bilim ve teknoloji politikaları hakkında çalışmak ve gerçekleştirilmesine katkı sağlama, araştırma ve geliştirme faaliyetlerini teşvik etme, destekleme ve yürütme, bilim ve teknoloji kültürünün geliştirilmesine öncülük etme amacıyla kurulmuş olan, tüzel kişiliğe, idari ve mali özerkliğge sahip, Sanayi ve Teknoloji Bakanlığıyla ilgili ve özel bütçeli bir kurumdur. Bu amaçlar doğrultusunda kurumun ilgi ve faaliyet alanlarında Türkçe ve yabancı dillerde süreli ve süresiz yayınlar yapmak, çoklu ortamlarda doküman ve belge oluşturmak ve bu tür yayın ve etkinlikleri desteklemek TÜBİTAK'ın görevlerinden biridir (TÜBİTAK, 2020a). Bu anlamda TÜBİTAK'ın kurulduğu ilk yıllardan itibaren, toplumumuzda bilimsel, teknolojik ve yenilik faaliyetlerine yönelik farkındalığın ve bilim okuryazarlığının geliştirilmesine yönelik etkinlikler; gerçekleştirilen yarışma ve şenliklerin yanı sıra yayınlanan dergi ve kitaplar aracılığıyla hayata geçirilmektedir (TÜBİTAK, 2020b). Dolayısıyla TÜBİTAK Bilim Toplum Daire Başkanlığı bünyesinde Popüler Bilim Dergileri Müdürlüğü tarafından, farklı yaş düzeylerinden bireylere hitap eden "Bilim ve Teknik", "Bilim Çocuk" ve "Meraklı Minik" dergileri ve "Bilim Genç" elektronik dergisi olmak üzere toplam dört dergi yayınlanmaktadır (TÜBİTAK Ulusal Gözlemevi [TUG], 2020). 
İlgili literatürde popüler bilim dergilerinin çeşitli açılardan incelendiği araştırmalar bulunmaktadır. Bu araştırmalar; popüler bilim dergilerinin üretim sürecindeki maddi yapının nasıl işlediğinin ve bu yapının dergilerin içerikleri üzerindeki etkilerinin incelenmesi (Dağtaş ve Yıldız, 2015); "popüler bilim” anlayışı içinde coğrafyanın yerinin belirlenmesi ve bu anlayışın değerlendirilmesi (Güner ve Çitçi, 2010); popüler bilim dergilerinin içerik, kaynaklar, yazım ve dil, görsellik ve bilimsellik yönünden popüler bilimi yansıtma düzeylerinin değerlendirilmesi (Özsevgeç ve diğerleri, 2017); çocuklara yönelik hazırlanmış popüler bilim dergilerinde yer alan evrensel değerlerin ve bu değerlere ne düzeyde yer verildiğinin tespit edilmesi (Alabay, Can, Kandemir ve Güney, 2018; Yeter, 2019); çocuk haklarına (Pembegül, 2019) ve bilim tarihine (Yavuzoğlu, 2018) popüler bilim dergilerinde yer verilme durumunun incelenmesi; dergi içeriğinin, öğretim programı ile ne ölçüde örtüştüğünün ve bilgilendirici bir eserde bulunması gereken özellikleri karşılama düzeyinin belirlenmesi (Dedeoğlu, Şahin, Ulusoy ve Ertem, 2011) olarak örneklendirilebilir.

$\mathrm{Bu}$ araştırmalar sonucunda popüler bilim dergilerinin kuruluş amacı ve süregelen yayın politikası gereği içerik, kullanılan dil, görseller ve bilimsellik özelliklerinin değişiklik gösterebileceği belirlenmiştir (Özsevgeç ve diğerleri, 2017). Bunun yanında dergilerin içeriklerinin; yayıncılık modeli, üretim biçimleri ve emek süreçleri gibi ekonomik politik faktörlerden etkilenebileceği görülmüştür (Dağtaş ve Yıldız, 2015). Ayrıca Bilim Çocuk dergisinin içerdiği konuların Milli Eğitim Bakanlığı (MEB) tarafından belirlenen öğretim programları ile doğrudan ilişkili olmadığı (Dedeoğlu ve diğerleri, 2011), bu dergide 2005 yılından sonra bilim tarihine verilen yerin azaldığı (Yavuzoğlu, 2018) ve çocuk dergilerinde bilimsellik değerine oldukça yer verildiği (Yeter, 2019) tespit edilmiştir. Meraklı Minik dergisinde ise 2012-2016 yılları arasında "sevgi, sorumluluk ve işbirliği" gibi evrensel değerlere yer verilirken, olumsuz değerlere yer verilmediği (Alabay ve diğerleri, 2018) ve Meraklı Minik ve Bilim Çocuk dergilerinin ilk basımından 2009 yılına kadar olan arşivlerinde çocuk haklarının olumsuz kullanımı olarak değerlendirilebilecek çok az örneğe rastlanıldığ görülmüştür (Pembegül, 2019).

Gelişimin ilk aşamalarında, kitle iletişim araçları insanların yeni bir teknoloji hakkındaki fikirlerinin ana kaynağı olabilir. Bu nedenle çeşitli medya kuruluşlarının gelişmekte olan bir bilim olarak nanoteknolojiyi nasıl ele aldıkları önemlidir (Lewenstein ve diğerleri, 2009). NBT ile ilgili yapılan çalışmalar incelendiğinde nano-görüntülerin kullanımıyla ilgili dergilerin incelendiği (Tseronis, 2018) ve nanoteknolojinin halka iletilmesi konusunu ele alan yayınlanmış hakemli makalelerin literatür taramasının incelendiği (Boholm ve Larsson, 2019) çalışmalar bulunmuştur. Ülkemizde ise NBT'nin Türkiye'de yayınlanan gazetelerde işlenişiyle ilgili çalışmalar bulunurken (Kamanlığlu ve Güzeloğlu, 2010; Şenocak, 2017), popüler bilim dergilerde işlenişiyle ilgili herhangi bir çalışmaya rastlanmamıştır.

Bir bilim dalına ait bilimsel içerikli çalışmaların popüler bilim yayınlarında kazandığı yoğunluk, ilgili bilim dalının popülerleştiğinin bir göstergesi olarak kabul edilmektedir (Güner ve Çitçi, 2010). Popülerleşme dediğimiz sadece halkın bilgilenmesi gibi basit bir konu değil, aynı zamanda bilim ve araştırmaların, siyasi tartışma ve kararlarda kullanılacak bilgi ve bakış açısının sağlanmasında önemli işlevlere sahip olduğu süreçlerde ve toplum hareketliliğinde önemli bir bileşendir (Pramling ve Säljö, 2007). Bu nedenle NBT'nin popülerliğinin değerlendirilebilmesi açısından popüler bilim dergilerinde NBT'ye ne kadar 
yer verildiğinin ve bu bilim alanlarının nasıl sunulduğunu incelenmesinin, gerekli olduğuna inanılmaktadır. Bu gereklilikten hareketle mevcut çalışmanın amacı NBT'nin TÜBİTAK tarafından yayınlanan popüler bilim dergilerine yansımalarını incelemektir.

\section{Yöntem}

$\mathrm{Bu}$ araştırmada nitel araştırma yöntemlerinden doküman analizi kullanılmıştır. Doküman analizi; kurumsal, klinik veya program kayıtları, not ve yazışmalar; resmi yayınlar ve raporlar; kişisel günlükler ile anket ve anketlere verilen açık uçlu yazılı cevaplardan elde edilen alıntılar veya tam pasajlarla çalışmayı içerir (Patton, 2002). Doküman analizi genellikle içerik analizi adı verilen özel bir analitik yaklaşım gerektirir (Marshall ve Rossman, 1999). İçerik analizi; insanların iletişimlerinin içeriğinin analiz edilmesiyle, insan davranışlarının dolaylı bir şekilde incelenmesini sağlayan bir tekniktir. Bu yolla bir kişinin veya grubun bilinçli ve bilinçsiz inançları, tutumları, değerleri ve fikirleri sıklıkla ortaya çıkarılabilir (Fraenkel ve Wallen, 2009). Türkiye'de basılan ve yayınlanan TÜBİTAK Popüler Bilim Dergilerinde yer alan nanobilim ve nanoteknoloji ile ilgili makaleler (NBTIM) bu çalışmada içeriği analiz edilmek üzere kullanılan dokümanlardır. Bu çalışma doküman analizi yöntemine göre yürütüldüğü için etik kurul izni gerektirmemektedir.

\section{Evren ve Örneklem}

$\mathrm{Bu}$ çalışmanın örnekleminin belirlenmesinde amaçlı örnekleme yöntemlerinden ölçüt örnekleme yöntemi kullanılmıştır. Ölçüt örnekleme yöntemi araştırmacılara önceden belirlenmiş bazı kriterleri karşılayan tüm vakaları gözden geçirme ve inceleme fırsatı sunar (Patton, 2002). Bu doğrultuda bu araştırma kapsamında incelenen dergilerin ve makalelerin seçiminde kullanılan ölçütler şunlardır:

- Dergi seçimi: Araştırma kapsamında incelenecek dergilerin; ülkemizin Bilim ve Teknoloji politikalarının belirlenmesinde öncü olan ve toplumun her kesiminde bu farkındalığı artırmak üzere çeşitli kitap ve dergiler yayınlayan (TÜBİTAK, 2020b) TÜBİTAK tarafından yayımlanan bilim dergileri olması dikkate alınmıştır.

- Elektronik arşiv: Bu çalışmada incelenen makalelerin seçiminde dergilerin elektronik arşivlerinden yararlanılmıştır. Dergilerin elektronik arşivlerinin tercih edilmesinde, internetin olduğu her ortamda ulaşılabilir olması, geçmişe dönük makale ve içeriklerine ulaşılabilmesi, tarama olanaklarının zengin olması, zamana ve mekâna bağlı olmaması (Yenikurtuluş, 2007), ayrıca araştırmacılar için maliyet açısından ekonomik olması belirleyici unsurlar olmuştur. İlk ölçüte göre belirlenen dört TÜBİTAK bilim dergisinin (Bilim ve Teknik, Bilim Çocuk, Bilim Genç ve Meraklı Minik) elektronik ortamdaki arşivlerine ulaşılıp ulaşılamaması dikkate alınmıştır.

- Uygun içerik: Seçilen dergilerin elektronik arşivlerinde "nano" kelimesi taratılmış ve arşivinde bu kelime ile ilgili makale bulunmayan Meraklı Minik dergisi araştırma kapsamına dâhil edilmemiştir. Ayrıca sadece elektronik ortamda yayınlanan Bilim Genç dergisi, derginin yayınlanma yılı olarak Bilim ve Teknik ve Bilim Çocuk 
dergilerine göre daha yeni olması, anahtar kelimenin taranması sonucunda farklı türde içeriklere ulaşılması (makale, söyleşi ve video vb.) nedeniyle araştırma kapsamına dâhil edilmemiştir.

Sonuç olarak, bu ölçütler doğrultusunda seçilen iki popüler bilim dergisi incelenmek üzere araştırmanın örneklemini oluşturmuştur. Bu dergilere ait bazı özellikler şunlardır:

- Bilim ve Teknik: TÜBİTAK tarafından genç ve yetişkinlere yönelik hazırlanan Bilim ve Teknik dergisi 1967 yılından itibaren aylık olarak yayınlanan popüler bilim dergisidir. Bu derginin amacı "gençleri bilimsel ve teknolojik araştırma alanlarına yönlendirmek ve gençlerin bu konularda çalışma isteğinin yaygınlaşmasını sağlamak" olarak belirtilmektedir. Güncel gelişmeler doğrultusunda belirlenen merak uyandırıcı bilimsel ve teknolojik konulardaki gelişmeler anlaşılır bil dil ile aktarılmaya çalışılmaktadır. Dergi içerisinde yer alan özgün makaleler ve haberler popüler bilim yazarları, araştırmacılar ve bilim insanları tarafından hazırlanmaktadır (TÜBİTAK, 2020c).

- Bilim Çocuk: TÜBİTAK tarafından yayınlanan popüler bilim dergilerinden bir diğeri Bilim Çocuk dergisidir. 1998 yılından itibaren aylık olarak yayınlanan bu dergi, yedi yaş ve üzeri çocuklara hitap etmektedir. Bu derginin amacı küçük yaştan itibaren çocuklara bilimi sevdirmek, bilim dünyasına katkı sağlayabileceklerini onlara fark ettirmek, okuma isteği ve merak duygusu uyandırmak, çocukları buluş yapmaya özendirmek ve yaşamın bir parçası olarak bilimi göstermektir. Yazıların herkesin anlayabileceği bir dille hazırlandığı dergide etkileşim köşeleri, etkinlik önerileri ve çizgi romanlar bulunurken derginin yanında masaüstü oyunu, oyun kartları, maske, maket, kitapçık ve poster gibi derginin içindeki yazıları destekleyici yönde ekler de verilmektedir (TÜBİTAK, 2020c).

\section{Veri Toplama Süreci}

Veri toplama sürecinde ilk olarak dergilerin elektronik arşivlerinde yer alan NBTiM'e ulaşabilmek için TÜBİTAK Popüler Bilim Dergileri Elektronik Dergi Uygulaması'nda bulunan arama çubuğu kullanılmıştır. NBTIM'in tamamına ulaşabilmek ve herhangi bir veri kaybını önlemek amacıyla arama çubuğunda "nano" kelimesi taratılmıştır. Tarama sonucu web sayfasında listelenen makaleler iki araştırmacı tarafından tek tek incelenerek;

- "Nano" kelimesini içermesine rağmen NBT ile ilgili olmayan veya belirsiz içerikteki makaleler,

- Makale içeriğindeki nesnenin küçük boyutlu olduğunu belirtmek için "nano" kelimesinin kullanıldığı makaleler (nano uydu vb.),

- Belirli bir yılda yayınlandıktan sonra, içeriği değiştirilmeden başka bir yılda tekrar yayınlanan makalelerin ilk yayınlanma tarihinden sonraki tüm tekrar yayınları,

- "Nano" kelimesinin yalnızca özel isimler, şirket adları, enstitü veya merkez adları olarak kullanıldığı makaleler (ODTÜ Nanoteknoloji ve Nanobiyoteknoloji Araştırma Merkezi, vb.) çalışmanın amaçlarıyla örtüşmediği gerekçesiyle manuel olarak 
elenmiştir.

Eleme işlemi sonrasında toplam NBT ile ilgili 111 makale veri analiz sürecine dâhil edilmiştir.

\section{Verilerin Analizi}

Veri toplama süreci sonucunda elde edilen makaleler; (i) yayınlandığı dergiye, (ii) yayınlanma yılına, (iii) içeriğine ve (iv) içeriğindeki yaklaşıma göre dağılımı bakımından analiz edilmiştir.

- Makalelerin yer aldığı dergiye göre dağılımı: Veri analizi sürecinde ilk olarak makalelerin hangi dergide yayınlandığı incelenmiştir. Elde edilen veriler frekans ve yüzde olarak yorumlanmıştır.

- Makalelerin yıllara göre dağılımı: Makalelerin yıl bazında dağılımı incelenmiştir. Elde edilen veriler frekans ve yüzde olarak yorumlanmıştır.

- Makalelerin içeriğine göre dağılımı: Makaleler içeriğine göre analiz edilirken öncelikle literatür taraması yapılmış ve NBT ile ilgili gazete haberlerinin analiz edildiği çalışmalar (Anderson, Allan, Petersen ve Wilkinsonvd, 2005; Davis, 2011; Kamanlıŏlu ve Güzeloğlu, 2010; Kjærgaard, 2010; Stephens, 2005) incelenmiştir. Daha sonra bu çalışmaların sonuçlarına göre gazete haberlerinin içerik analizinde ortaya çıkan kategorilerin ve bu kategorilere dâhil edilen makalelere verilen kodların listesi oluşturulmuştur. Bu listeden yararlanarak mevcut çalışmada benimsenen kategoriler ve bu kategorilerde yer alan makaleler için kullanılan kodlar belirlenmiştir. Bu işlem sonucunda belirlenen toplam 14 kategori ve bu kategorilere ait kodlar Tablo 1' de verilmiştir. Analiz sonucu elde edilen veriler frekans ve yüzde olarak yorumlanmıştır. 
Tablo 1. Makalelerin İçeriklerine Göre Oluşturulan Kategori ve Kodlar

\begin{tabular}{|c|c|}
\hline Kategoriler & Kodlar \\
\hline Kitap, dergi, radyo, film tanıtımı, eleştiriler & Kitap, dergi, dergide yayınlanmış, film \\
\hline $\begin{array}{c}\text { Ulusal ve uluslararası politikalar - } 2023 \\
\text { vizyonu }\end{array}$ & Strateji, politikalar \\
\hline Bilimsel keşif, proje ve araştırmalar, ürünler & $\begin{array}{c}\text { İcat ve icat edilebilecek ürünler, keşif, ürün, bilimsel } \\
\text { araştırma ve projeler, ilk üretim, AR-GE, üniversite } \\
\text { çalışmaları }\end{array}$ \\
\hline İşler, şirketler ve ticari uygulamalar & $\begin{array}{l}\text { Üretim, seri üretim ve seri üretime yönelik kuvvetli } \\
\text { işaret, piyasada satış, ticarileşme, şirketler }\end{array}$ \\
\hline Sosyal etki & Yaşama etki \\
\hline Risk & Risk, tehlike, tehdit, maruz kalmak \\
\hline $\begin{array}{l}\text { Özel bütçe ve kamu bütçesi, çeşitli } \\
\text { destekleme programları ve kuruluşlar }\end{array}$ & Bütçe, yatırım, teşvik, destekleme programı \\
\hline Eğitim ve kariyer durumları - ders kitapları & $\begin{array}{c}\text { Eğitim, yüksek lisans, doktora, nano eğitim ile ilgili } \\
\text { etkinlikler }\end{array}$ \\
\hline $\begin{array}{l}\text { Medikal keşif ve projeler, çevre ve halk } \\
\text { sağlığı }\end{array}$ & $\begin{array}{c}\text { Sağlık, tıp, araştırma, keşif, ürün, çip, kanser, çevre, } \\
\text { kirlilik, antibakteriyel }\end{array}$ \\
\hline Ulusal güvenlik ve askeri uygulamalar & Savunma, askeri, radar \\
\hline Ekonomik etkiler ve iş gücü & Kazanç, iş olanağı, ekonomik etki, finansal \\
\hline Kutlamalar ve ödüller & Ödül \\
\hline $\begin{array}{l}\text { Geleceğe yönelik beklentiler - tahminler - } \\
\text { planlamalar }\end{array}$ & Gelecek, beklentiler, tahminler \\
\hline Diğer & Konferans, kongre, panel, seminer \\
\hline
\end{tabular}

- (iv) Makalelerin içeriğindeki yaklaşıma göre dağılımı: Makaleler içeriğindeki yaklaşıma göre analiz edilirken, makalenin okuyucuya verdiği mesaj incelenmiş ve makaleler literatürle uyumlu olarak; olumlu, olumsuz ve nötr ton şeklinde kodlanmıştır. Tunçel, Vuran Doğan ve Ardıç Çobaner (2012), yaptıkları çalışmada haberlerin tonunu, kullanılış şekillerine göre kabul eden, öven ve olumlu gösteren haberleri pozitif ton; kabul etmeyen, reddeden, eleştiren ve olumsuz gösteren haberleri negatif ton ve diğer haberleri nötr ton olmak üzere üç şekilde ele almışlardır. Bu kriterlerden yola çıkılarak mevcut çalışmada; ülkeye, insan sağlı̆̆ına, çevreye ve toplum problemlerine fayda sağlayan ya da sağlayacağı düşünülen ürün, proje ve fikirler içeren, okuyucuda olumlu duygular uyandıran makaleler olumlu ton kategorisine dâhil edilmiştir. NBT'nin risklerini ifade eden, zararlı olduğunu ya da olabileceğini savunan, yeterince anlaşılmadığından ve bu konularda geri kalınması sonucunda oluşabilecek zararlardan bahseden makaleler olumsuz ton kategorisine dâhil edilmiştir. Bunların dışında kalan, olumlu yada olumsuz olarak değerlendirilebilecek bir görüş bildirmeyip, konuyu tarafsız olarak ele alan veya olumlu ve olumsuz durumları aynı oranda içeren makaleler nötr ton kategorisine dâhil edilmiştir. Elde edilen veriler frekans ve yüzde olarak yorumlanmıştır.

\section{Pilot Çalışma}

Araştırmanın pilot çalışması kapsamında Bilim Çocuk dergisinde yer alan makaleler birbirinden bağımsız çalışan iki araştırmacı tarafından incelenmiştir. Makalelerin kodlama işleminin tamamlanmasının ardından araştırmacılar tarafından oluşturulan analiz listeleri karşılaştırılmış ve fikir birliği-fikir ayrılığı durumları belirlenmiştir. Görüş ayrılı̆̆ı olan 
kategoriler üzerinde görüş birliği sağlamak üzere tartışmalar yapılmıştır. Miles ve Huberman'ın (1994) güvenirlik formülü [Güvenirlik = Görüş Birliği / (Görüş Birliği + Görüş Ayrılığı)] aracılığıyla ilk listeler için hesaplanan kodlayıcılar arası güvenirlik katsayısı .91 olup, farklılıkların giderilmesiyle ulaşılan son liste için güvenirlik katsayısı .95' e yükselmiştir. Pilot çalışmanın ardından asıl uygulamaya geçilmiş ve tüm kodlamalar pilot çalışmayı yürüten iki araştırmacı tarafından yapılmıştır.

\section{Bulgular}

\section{Makalelerin Yer Aldığı Dergiye Göre Dağılımına İlişkin Bulgular}

NBTIMM'in yer aldığı dergiye göre dağılımına ilişkin bulgular Şekil 1'de verilmiştir.

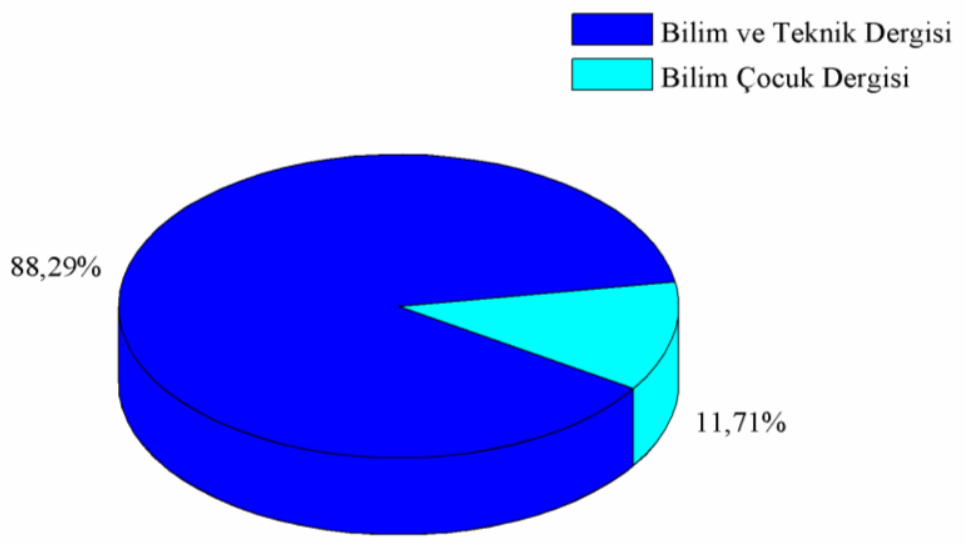

Şekil 1. NBTiM'in Yer Aldığı Dergiye Göre Dağılımı

Şekil 1'de verilen NBTIM'in yer aldığı dergiye göre dağılımları incelendiğinde; makalelerin \%88,29'sinin Bilim ve Teknik dergisinde, \%11,71'inin Bilim Çocuk dergisinde olduğu görülmektedir.

\section{Makalelerin Yıllara Göre Dağılımına İlişkin Bulgular}

NBTIM' in yıllara göre dağılımına ilişkin bulgular Şekil 2' de verilmiştir. 


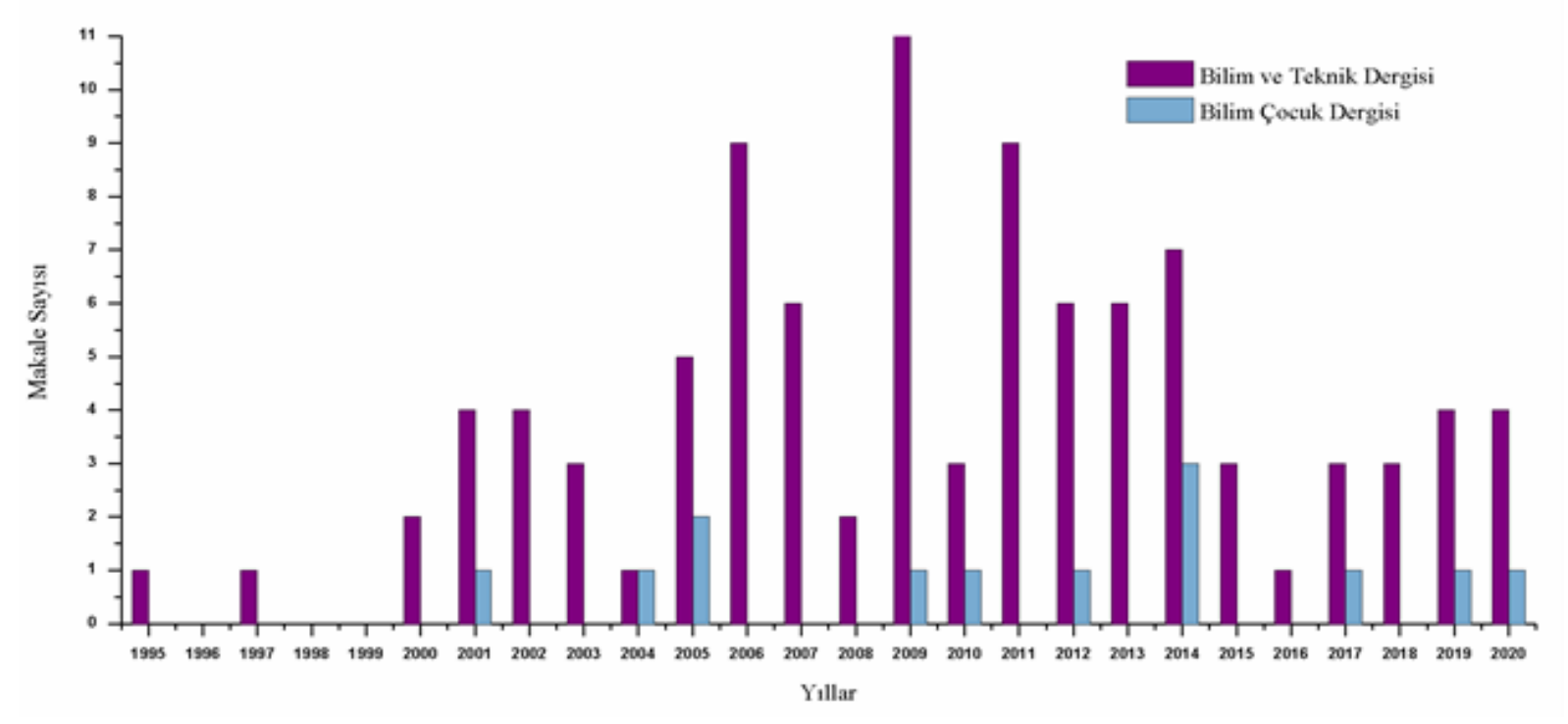

Şekil 2. NBTiM'in Yıllara Göre Dağılımı

Şekil 2' de verilen NBTIMM' in yıllara göre dağılımı incelendiğinde; süreç içinde artış ve azalışlar olmakla birlikte, Bilim ve Teknik dergisinde NBT ile ilgili ilk makalenin 1995 yılında yayınlandığı görülürken, Bilim Çocuk dergisinde 2001 yılında yayınlandığ1 tespit edilmiştir. NBT ile ilgili en çok makalenin yayınlandığı yıllar incelendiğinde, Bilim ve Teknik dergisinde 2009 yılında 11 makale yayınlanırken, Bilim Çocuk dergisinde 2014 yılında 3 makalenin yayınlandığı tespit edilmiştir. NBT ile ilgili en az makalenin yayınlandı̆̆ı yıllar incelendiğinde, Bilim ve Teknik dergisinde 1995, 1997, 2004 ve 2016 yıllarında 1'er makale yayınlanırken, Bilim Çocuk dergisinde 2001, 2004, 2009, 2010, 2012, 2017, 2019 ve 2020 yıllarında 1'er makalenin yayınlandığı tespit edilmiştir.

\section{Makalelerin İçeriğine Göre Dağılımına İlişkin Bulgular}

NBTIM'in içeriğine göre dağılımına ilişkin bulgular Şekil 3’te verilmiştir. 


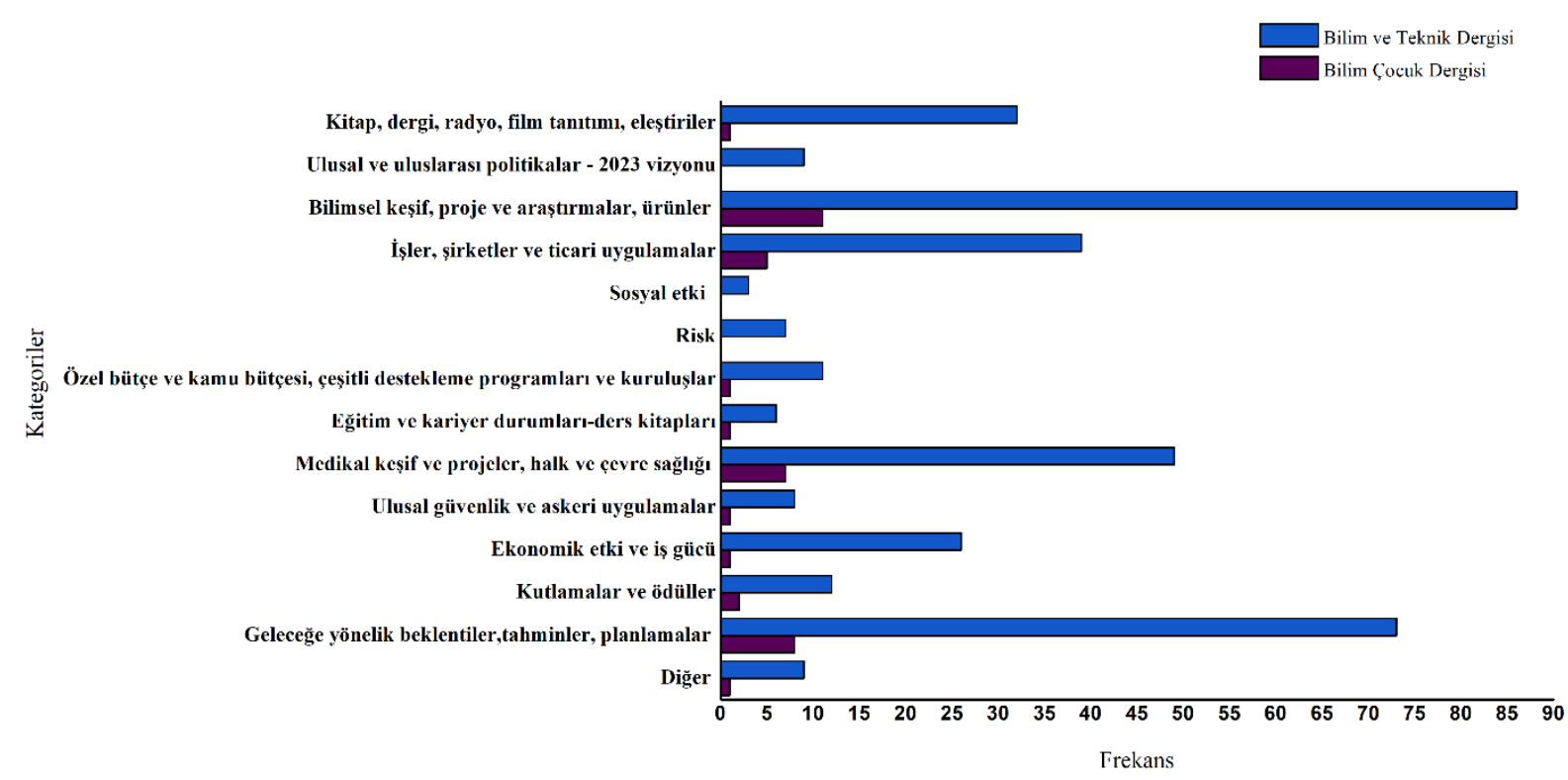

Not: Analiz sırasında bazı makaleler birden fazla kategoriye dâhil edilmiştir.

\section{Şekil 3. NBTiM'in İçeriğine Göre Dağılımı}

Şekil 3'te görüldüğü gibi, Bilim ve Teknik dergisinde NBTIM'in en yüksek oranda yer aldığ1 kategoriler sırasıyla; "Bilimsel keşif, proje ve araştırmalar, ürünler" (\%23,24), "Geleceğe yönelik beklentiler, tahminler, planlamalar" (\%19,73), "Medikal keşif ve projeler, halk ve çevre sağlığı" (\%13,24), "İşler, şirketler ve ticari uygulamalar" (\%10,54) kategorileri olmuştur. Buna karşılık NBTIM'in en düşük oranda; "Risk" (\%1,89), "Eğitim ve kariyer durumları-ders kitapları" (\%1,62), "Sosyal etki" $(\% 0,81)$ kategorilerinde yer almıştır.

Bilim Çocuk dergisinde en yüksek oranda yer alan kategoriler sırasıyla; "Bilimsel keşif, proje ve araştırmalar, ürünler" (\%28,21), "Geleceğe yönelik beklentiler, tahminler, planlamalar" $(\% 20,51)$, "Medikal keşif ve projeler, halk ve çevre sağlığı” (\%17,95), "İşler, şirketler ve ticari uygulamalar" (\%12,82) kategorileri olmuştur. Buna karşılık en düşük oranda; "Kitap, dergi, radyo, film tanıtımı, eleştiriler" (\%2,56), "Özel bütçe ve kamu bütçesi, çeşitli destekleme programları ve kuruluşlar" (\%2,56), "Eğitim ve kariyer durumları-ders kitapları" $(\% 2,56)$, "Ekonomik etki ve iş gücü" $(\% 2,56)$, "Ulusal güvenlik ve askeri uygulamalar" $(\% 2,56)$ ve "Diğer" (\%2,56) kategorilerinde yer almıştır. Bunun yanında "Risk", "Sosyal Etki" ve "Ulusal ve uluslararası politikalar-2023 vizyonu" kategorilerinde yer alan makalelerin olmadığ görülmektedir.

\section{Makalelerin İçeriğindeki Genel Yaklaşıma Göre Dağılımına İlişkin Bulgular}

NBTIMM'in içeriğindeki genel yaklaşıma göre dağılımına ilişkin bulgular Şekil 4'te verilmiştir. 

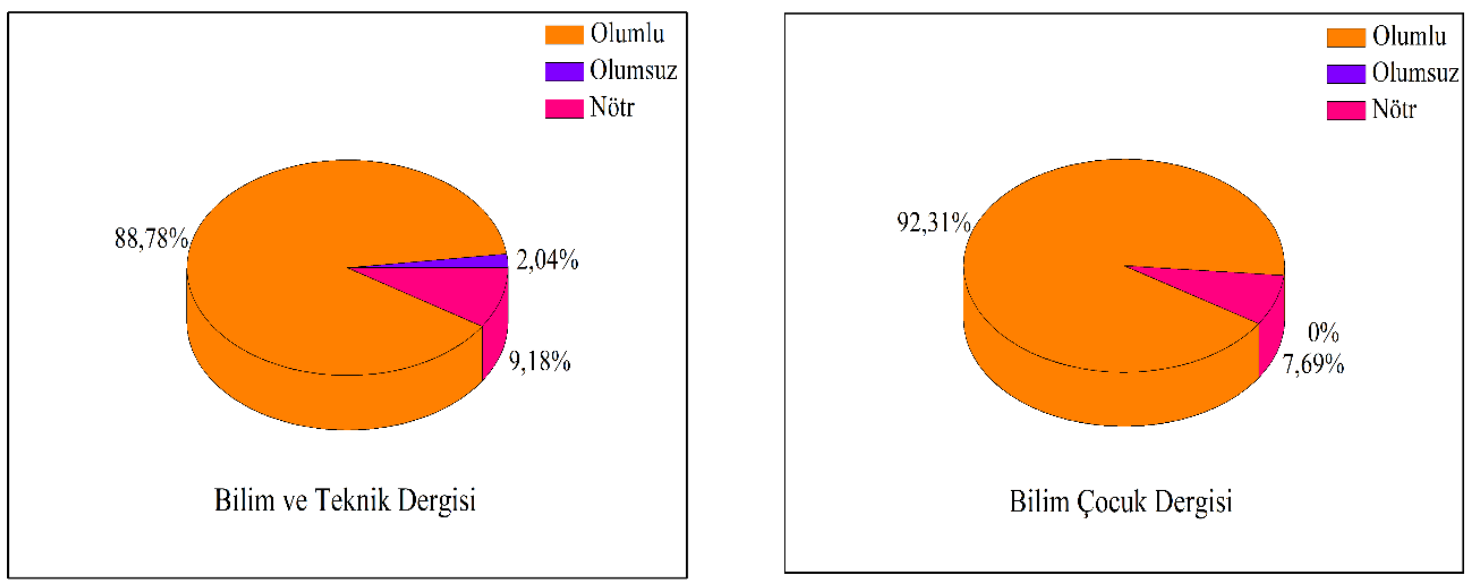

Şekil 4. NBTİM'in İçeriğindeki Genel Yaklaşıma Göre Dağılımı

Şekil 4'te verilen Bilim ve Teknik ve Bilim Çocuk dergilerinde yayınlanan NBTIM'in içeriğindeki genel yaklaşıma göre dağılımı incelendiğinde, Bilim ve Teknik dergisindeki makalelerin; \%88,78'inin olumlu, \%9,18'sinin nötr ve \%2,04'ünün olumsuz tonda sunulduğu görülmektedir. Bunun yanında Bilim Çocuk dergisindeki makalelerin \%92,31'inin olumlu, \%7,69'unun nötr tonda sunulduğu görülürken, olumsuz tonda makalenin bulunmadığı tespit edilmiştir.

\section{Tartışma}

NBT'nin TÜBİTAK tarafından yayımlanan popüler bilim dergilerine yansımalarını incelenmek amacıyla yapılan bu çalışmanın bulguları aşağıda ilgili literatür kapsamında maddeler halinde tartışılmış ve yorumlanarak sonuçlara ulaşılmıştır.

\section{Makalelerin Yayınlandığı Dergiye Göre Dağılımına İlişkin Tartışma}

NBTIMM'in yayınlandığı dergiye göre dağılımı incelendiğinde Bilim Çocuk dergisine oranla Bilim ve Teknik dergisinde daha fazla makalenin yer aldığı tespit edilmiştir. Bu durum dergilerin hedef kitlesinin genişliği, yaş düzeyi ve ilgi alanları ile ilişkilendirilebilir. TÜBİTAK Popüler Bilim Dergileri ekibinin katılımıyla popüler bilim yazarlığı üzerine bir üniversitede gerçekleştirilen söyleşide, popüler bilim dergileri için yazı hazırlama sürecinde hedef okuyucu kitlesinin tanımlanması gerektiği ifade edilmiştir. Ayrıca çocuklar ve gençler için yazılar yazılırken hedef yaş grubundakilerin ihtiyaç ve özelliklerinin dikkate alınması gerektiği belirtilmiştir (Havadis, 2018). Yazı hazırlama sürecinde dikkat edilmesi gereken diğer husus ise, hazırlanan çalışmaların, hedef kitlenin ortalama bilgi düzeyine uygun olmasının beklenmesidir (TÜBİTAK, t.y.). Mevcut araştırmada da incelenen Bilim ve Teknik dergisi gençlere ve yetişkinlere, Bilim Çocuk Dergisi ise yedi ve üzeri yaştaki çocuklara yönelik hazırlanmakta olup (TÜBİTAK, 2020c), farklı hedef kitlelere sahiptir. Dolayısıyla Bilim ve Teknik dergisinin daha geniş bir kitleye hitap ettiği, buna karşılık Bilim Çocuk dergisinin hedef kitlesinin nispeten daha sinırlı olduğu söylenebilir.

Öğretmenler popüler bilim dergilerinin, öğrencilerin bilimle aralarında bir bağ kurmalarını ve bilimsel ve teknolojik gelişmelerin farkına varmalarını sağladığını düşünmektedirler (Yavuz 
ve Balkan Kıyıcı, 2012). Lu'nun (2009) mühendislik öğrencileriyle yaptığı bir çalışmada öğrencilerin nano kelimesini en çok popüler bilim dergilerinden duydukları tespit edilmiştir. Bunlara ek olarak ülkemizde ortaokul öğrencilerinin nanoteknoloji konusundaki bilgi düzeylerinin orta düzeyde olduğu görülmüştür. Nanoteknoloji konusundaki duyumların artmasının ise öğrencilerin bilgi düzeylerini arttırmaya yönelik etkisinin olduğu tespit edilmiştir (Ekli, 2010). Bu doğrultuda popüler bilim dergilerinin bilgi düzeylerini arttırmaya yönelik bir işleve sahip olduğu da söylenebilir. Ayrıca yazıların hazırlanma süreci ile ilgili dikkat edilmesi gereken bu hususlar popüler bilim yazarlarını daha küçük yaş grupları için NBT ile ilgili uygun nitelikte çalışmalar ortaya çıkarma konusunda sınırlandırmış olabilir.

2017 yılında T.C. Bilim Sanayi ve Teknoloji Bakanlığı (BSTB) tarafından yayınlanan Türkiye Nanoteknoloji Stratejisi ve Eylem Planı'nda (2017-2018), Türkiye'de nanoteknoloji alanında çeşitli üniversitelerde lisansüstü öğretim programlarının yer aldığı ve nanoteknoloji araştırma merkezlerinin bulunduğu ifade edilmiştir (BSTB, 2017). Buna karşılık NBT'nin lise düzeyinde sınırlı bir seviyede öğretiminin yapıldığı görülürken (Kılınç Alpat, Uyulgan, Şeker, Altaş ve Gezer, 2017; Sagun Gököz ve Akaygün, 2014), ilkokul ve ortaokul seviyesinde öğretimsel uygulamalara rastlanmamıştır. Bu doğrultuda ülkemizde genç ve yetişkinlere yönelik daha fazla NBT öğretim olanağının sağlanmasıyla, bu yaş grubuna yönelik yayın yapan Bilim ve Teknik dergisinde NBTIM'in sayısının fazla olması ilişkilendirilebilir.

\section{Makalelerin Yıllara Göre Dağılımlarına İlişkin Tartışma}

NBTIM'in yıllara göre dağılımı incelendiğinde, toplamda 2009 yılında en fazla makalenin olduğu görülürken, makale sayılarında yıllara göre dalgalanmalar olduğu tespit edilmiştir. İçinde bulunulan dönem ve dönemin güncel olayları bir bilim dalına yönelik toplumsal ilgi ile doğrudan ilişkilidir. Popüler bilim dergileri de yayınlanma amaçları gereği güncel olayları yakalamak ve bilimsel gündemi takip etmek durumundadır. Dolayısıyla popüler bilim yayınlarının bilim dallarına gösterdiği ilgi, bilimsel gelişmelerin yaşandığı dönemle doğrudan alakalıdır (Güner ve Çitçi, 2010). Ülkemizde 1990'lı yılların başında dünyadaki nanoteknoloji politikalarına uzak kalınırken 2000'li yılların başından itibaren nanoteknoloji ile ilgili çeşitli adımlar atılmaya başlanmıştır (Türk Sanayicileri ve İşadamları Derneği, 2008). Örneğin, TÜBİTAK tarafından 2004 yılında yayınlanan Ulusal Bilim ve Teknoloji Politikaları-Vizyon 2003-2023 Strateji Belgesi'nde (TÜBİTAK, 2004), öncelikli stratejik teknoloji alanlarından biri olarak belirlenen nanoteknolojinin hızla yaşamımıza girmekte olduğu belirtilmiştir. Ayrıca Devlet Planlama Teşkilatı (DPT) tarafından hazırlanan ve 2006 yılında resmî gazetede yayınlanan Dokuzuncu Kalkınma Planı'nda (2007-2013) nanoteknoloji gibi alanların gelecekte öne çıkacağı ve öncelikli alanlar olarak destekleneceği ifade edilmiştir (DPT, 2006). Bu gelişmeden bir yıl sonra DPT Müsteşarlığı, Bilkent Üniversitesi'nden sunulan Ulusal Nanoteknoloji Araştırma Merkezi (UNAM) projesi aracılığı ile ulusal nitelikte bir nanoteknoloji merkezi kurulması için büyük bir destek sağlamıştır (Çıracı, 2007). Kurulan bu araştırma merkezinde son teknolojik cihazlarıyla hizmet veren temiz oda laboratuvarı ise 2009 yılında faaliyete geçirilmiştir (Ulusal Nanoteknoloji Araştırma Merkezi Malzeme Bilimi ve Araştırma Enstitüsü, 2013). Dikkat çeken bir diğer gelişme ise TÜBİTAK 2009 yılı ödülleri incelendiğinde NBT alanında çalışma yapan iki bilim insanı TÜBİTAK Özel Ödülü ve Teşvik Ödülüne layık görülmüştür (TÜBİTAK, 2009). TÜBİTAK Bilim ve Teknik ve Bilim Çocuk dergilerinde yayınlanan makale sayısının yıllara göre gösterdiği değişkenlik de bu yıllarda 
yaşanan NBT ile ilgili güncel gelişmelerle ilişkilendirilebilir.

\section{Makalelerin İçeriğine Göre Dağılımına İlişkin Tartışma}

NBTIMM'in içeriklerine göre dağılımı incelendiğinde; her iki dergide de en fazla sayıda makale ile "Bilimsel keşif, proje ve araştırmalar, ürünler" kategorisinin öne çıtı̆̆ı görülmüştür. Popüler bilim dergilerinin içerikleri güncel gelişmeler 1şı̆̆ında belirlenmekte olup merak uyandıracak bilimsel ve teknolojik konular herkesin anlayabileceği bir dille aktarılmaya çalışılır. Dergilerde yayımlanan haberler ve makaleler araştırmacılar, popüler bilim yazarları ve bilim insanları tarafından hazırlanmaktadır (Yazır, 2018). Bilim ve Teknik Dergisi içerdiği konu alanları yönünden incelendiğinde çoğunlukla teknoloji ve fen bilimleri konularına yer verdiği görülmektedir (Özsevgeç ve diğerleri, 2017). Bilim ve Teknik Dergisinde ekonomik olarak kâr amacı güdülmemekte, dergi çalışanları daha fazla satmak gibi amaçlar edinmedikleri ve dergiye reklam alınmadığ oluşturulmaktadır (Dağtaş ve Yıldız, 2015). Bu doğrultuda Bilim ve Teknik dergisinin amacı en kapsamlı şekilde bilimsel ve teknolojik çalışmaları insanlara tanıtmak, açık ve anlaşılabilir bir dil kullanarak çeşitli alanlardaki yeniliklere ve buluşlara ilgi duyan kişilerin bilgiye ulaşmalarını sağlamaktır. Bilim Çocuk Dergisinin amacı ise küçük yaştan itibaren bilimi çocuklara sevdirmek, fark ettirmek ve onlara yaşamla bilimin iç içe olduğunu göstermektir (TÜBİTAK, 2020c). Mevcut çalışmada NBTİM'in içeriklerinde bilimsel araştırmalar, projeler ve keşifler, icat edilmiş ve icat edilebilecek ürünler ve AR-GE üniversite çalışmalarının baskın bir şekilde görülmesi dergilerin amaçlarına hizmet edecek nitelikte konu ve yayınlara yer verdiği şeklinde değerlendirilebilir.

Nanoteknoloji, oluşturulacak ileri teknolojili ürünlere yeni özelliklerin kazandırılması için bilimsel ve teknolojik yeterliliğe sahip olunması gereken alanlardan birisidir (TÜBİTAK, 2004). Ülkemizde nanoteknolojiye yönelik çalışmaları desteklemek, bu alanda uzmanların yetişmesini sağlamak ve dünyadaki gelişmeleri yakalayarak ulusal bir nanoteknoloji temelini kurmak hedeflenerek devlet desteği ile nanoteknoloji merkezleri kurulmaya başlanmıştır (BSTB, 2017). Bu doğrultuda ülkemizde nanoteknolojiye yönelik bilimsel araştırmaların ve projelerin gerçekleşebilmesi için çeşitli adımlar atıldığı ve atılan bu adımların popüler bilim dergilerine de yansıdığı söylenebilir. Ayrıca medyanın, nanoteknolojiyi bilimsel bir açıdan ele alması ve böylece bilim insanlarının çoğunlukla medyada yer alan başkahramanlar olarak görülmesi (Metag ve Marcinkowski, 2014) bu çalışmada elde edilen sonuçlarla ilişkilendirilebilir.

Günümüz teknolojileri içinde önemli bir yeri olan nanoteknolojinin 9. ve 10. Kalkınma Planları'nda gelecekte ön planda olan teknolojiler içinde yer alacağı ifade edilmiştir (DPT, 2006; T.C. Kalkınma Bakanlığı, 2013). Ayrıca Türkiye Cumhuriyeti Cumhurbaşkanlığı Strateji ve Bütçe Başkanlığı (SBB) tarafından 2019 yılında yayınlanan On Birinci Kalkınma Planı'nda Milli Teknoloji Hamlesinin gerçekleştirilebilmesinin, kritik teknolojiler arasında verilen nanoelektronik teknolojisine yönelik yol haritalarının çizilmesi, gerekli olan alt yapının kurularak gerekli nitelikli personelin yetiştirilmesi ve toplumun bu alanlara yönlendirilmesi ile sağlanacağı belirtilmektedir (SBB, 2019). Popüler bilim dergilerinde yayınlanan makalelerde de "Geleceğe yönelik beklentiler, tahminler, planlamalar" kategorisinin öne çıkması nanoteknolojinin geleceğine yönelik atılan ve atılması planlanan bu tür adımlar ve ardından 
yaşanan gelişmeler ile ilişkilendirilebilir.

Çeşitli ülkelere ait medya kaynaklarında nanoteknolojinin başta bilimsel faydaları olmak üzere ekonomik ve tıbbi faydalarından sıkça bahsedilmekle birlikte, bu faydalara, risklerine göre daha fazla değinildiği görülmüştür. Bu noktada çarpıcı olan, nispeten fazla sayıdaki tanımlanmamış risktir. Bu durum, olası risklerin gerçekte neye yol açacağının veya açabileceğinin genellikle net olmadığını göstermektedir. Riskin kapsamı genellikle çok düşük olsa da, nanoteknoloji belirsizliklerle oldukça yakından ilişkilidir (Metag ve Marcinkowski, 2014). Bu teknoloji sıklıkla sağlık ve çevresel riskler hakkında eksik bilgi ile nitelendirilmektedir (Guenther ve Ruhrmann, 2013). Kaynağı belirsiz bilimsel bilgiler ya da medya abartmaları yoluyla nanoteknolojinin itibarının zedelenmesi gibi bazı durumlarda toplumun nanoteknolojiye yönelik risk algısının, yüksek olabileceği düşünülmektedir. Ayrıca nanoteknolojinin risklerinin nasıl kontrol edildiği ya da edilebileceği konusunda topluma yetersiz bilgi iletilmesi de daha yüksek risk algısına neden olabilir (International Risk Governance Council [IRGC], 2006). Benzer şekilde nanoteknolojinin olumsuz özelliklerinin yeteri kadar bilinmemesi nedeniyle bu konudan fazla bahsedilmesinin de toplumda panik durumuna neden olabileceği düşünülmektedir (Groboljsek ve Mali, 2012). Bu sebepler, NBT'nin risklerine popüler bilim dergilerinde az değinilmiş veya hiç değinilmemiş olmasını açıklayabilir.

$\mathrm{Bu}$ çalışmada elde edilen bulgulara benzer nitelikteki bulgular farklı ülkelerde, NBT ile ilgili gazete haberlerinin incelendiği araştırmalarda da elde edilmiştir. Analizi yapılan haberlerin içeriklerinde NBT'nin bilimsel yönlerinin baskın olarak vurgulandığı görülmüştür (Anand ve Deepa, 2013; Anderson ve diğerleri, 2005; Groboljsek ve Mali, 2012; Haslinger ve Hocke, 2009; Kamanlığlu ve Güzeloğlu, 2010; Şenocak, 2017; Stephens, 2005). Nanoteknoloji, haber medyasında ve kitle iletişim sağlayan diğer araçlarda bilimsel keşifler ve teknolojik yenilikler, riskler, insan sağlığı ve çevre ile ilgili konularda bir kesişme sunmaktadır (Weaver, Lively ve Bimber, 2009). Buna karşılık İngiltere (Anderson ve diğerleri, 2005), Amerika (Stephens, 2005), Türkiye (Kamanlığlu ve Güzeloğlu, 2010) ve Danimarka (Kjærgaard, 2010) medyasında yer alan haberler içeriklerine göre incelendiğinde nanobilim ve nanoteknolojinin sosyal etki ve risklerine yönelik haberlerin nispeten düşük frekansa sahip olduğu tespit edilmiştir.

\section{Makalelerin İçeriğindeki Genel Yaklaşıma Göre Dağılımına İlişkin Tartışma}

$\mathrm{Bu}$ çalışmada NBTIMM'in içeriğindeki genel yaklaşıma göre dağılımı incelendiğinde, makalelerin \%89,32'sinin olumlu bir yaklaşım içerdiği tespit edilmiştir. Benzer şekilde NBT ile ilgili gazete haberlerinin incelendiği çalışmalarda da haber içeriğinin genel olarak olumlu bir yaklaşımla ele alındığı görülmüştür (Kamanlıŏlu ve Güzeloğlu, 2010; Kjærgaard, 2010; Metag ve Marcinkowski, 2014; Stephens, 2005). Bu noktada medyanın ve referans olarak sundukları kaynakların nanoteknolojiyi nasıl değerlendirdikleri oldukça önemlidir. Medya bilimsel araştırma ve geliştirmeye odaklanır ve bilim insanları nanoteknolojideki gelişmeleri tanıtmaya çalıştıkça, medya bu kapsamda olumlu tarafta kalır (Metag ve Marcinkowski, 2014). Bu duruma paralel olarak farklı yaş ve eğitim düzeyinden katılımcılarla yapılan çalışmalarda, NBT'nin faydalarının risklerinden daha fazla olduğu yönündeki alg1 ve görüşler (Cobb ve Macoubrie, 2004; Ekli, 2010; Farshchi, Sadrnezhaad, Nejad, Mahmoodi ve İbrahimi Ghavam Abadi 2011; Kahan, Slovic, Braman, Gastil ve Cohenvd, 2007; Macoubrie, 2006; Şenel Zor ve 
Aslan, 2018; Senocak, 2014) dergilerdeki nanoteknoloji makalelerinin olumlu yaklaşımı ile ilişkilendirilebilir. Bu durumun bir sonucu olarak, Scheufele ve Lewenstein (2005) tarafından ifade edildiği gibi medya kaynaklarının bilim ve iş dünyasındaki yeni teknolojilerin toplumda daha olumlu bir yönde şekillenmesini sağlayan bir rol üstlendiği söylenebilir. Yani bu medya organları nanoteknolojinin potansiyel yararlarını vurgulamakta ve topluma konunun genel olarak daha olumlu bir fotoğrafını sunmaktadır.

Bu çalışmada elde edilen sonuçlar doğrultusunda, sonuçlardan muhtemel etkilenebilecek ve sonuçların fayda sağlayabileceği gruplar olarak; benzer bir konuda çalışmak isteyen araştırmacılara, dergi editörlerine, yazarlarına ve yayıncılarına öneriler sunulmuştur.

Bu çalışmada TÜBİTAK Popüler Bilim Dergilerinden olan Bilim ve Teknik dergisi ve Bilim Çocuk dergileri ele alınmıştır. Gelecekte bu alanda çalışma yapmak isteyen araştırmacılar, bu çalışmada ele alınmayan ulusal veya uluslararası diğer popüler bilim dergilerinde NBT'nin ele alınışı üzerine araştırmalar yapabilir ve elde ettikleri sonuçların benzerlik, farklılık ve nedenlerinin ortaya çıkarılması ile literatüre katkı sağlayabilir.

NBT'nin, orta yaş çocuklarının somut ve yaratıcı yollarla ilgisini çekmek, bilim alanının bütününü öğrenmelerini motive etmek için sahip olduğu potansiyel (Chang, 2006; Ng, 2009) dikkate alınarak, çocukların NBT ile erken yaşlarda tanışmasının sağlanması, yeni gelişen teknolojilere ve meslek alanlarına ilgilerini çekme noktasında bir fırsat olarak değerlendirilebilir. Bu doğrultuda NBT'nin sahip olduğu potansiyel ve bu alanların geleceği bakımından önemli bir adım olarak daha küçük yaş gruplarına hitap eden yayınlarda da NBT'ye yönelik daha fazla çalışmaya yer verilebilir.

Ayrıca bu tür yayınlarda hedef kitleye yönelik NBT ile ilgili evde veya okulda yapılabilecek türde etkinlikler sunulabilir.

Medya araçlarını daha etkin kılmak üzere medyada NBT için ve bunlar gibi yeni ortaya çıkan diğer teknolojiler için tanıtıcı ve bilgilendirici yayınlara yer verilerek (Şenel Zor, 2017) ilgili teknolojinin insanlara sunduğu tüm faydalı olanakların yanı sıra risk taşıyan olasılıklarına değinilebilir.

\section{Araştırmacıların Katkı Oranı}

$\mathrm{Bu}$ çalışmada veri toplama süreci, kaynakların eldesi birinci ve ikinci yazarlar tarafından gerçekleştirilmiştir. Çalışmanın yöntem kısmı üçüncü, dördüncü ve beşinci yazarlar tarafından organize edilmiştir. Verilerin analizleri ve yazım aşaması tüm yazarların katkılarıyla gerçekleştirilmiştir.

\section{Çatışma Beyanı}

Yazarlar potansiyel bir çıkar çatışması olmadı̆̆ını beyan ederler.

\section{Kaynakça}


Akoğlu, A. (2005). Popüler bilim yayıncılığı ve gökyüzü gözlem etkinlikleri. Journal of Istanbul Kültür University. 3(2), 1-4.

Aktürk, C. (2013). ZnO nano sistemlerinin sentezlenmesi ve manyetik özelliklerinin elektron paramanyetik rezonans (EPR) spektroskopisi ile incelenmesi. Yayınlanmamış yüksek lisans tezi, Hacettepe Üniversitesi Fen Bilimleri Enstitüsü, Ankara.

Alabay, E., Can, B. H., Kandemir, A. B. ve Güney, K. (2018). TÜBİTAK tarafından yayınlanan Meraklı Minik Çocuk Dergisinin değerler açısından incelenmesi. Değerler Eğitimi Dergisi, 16(35), 7-26.

Anand, M. ve Deepa, N. (2013). Understanding trends and changes in media coverage of nanotechnology in India. Journal of Scientometric Research, 2(1), 70. DOI: 10.4103/23200057.115875

Anderson, A., Allan, S., Petersen, A. ve Wilkinson, C. (2005). The framing of nanotechnologies in the British newspaper press. Science Communication, 27(2), 200-220. DOI: $10.1177 / 1075547005281472$

Baalousha M., How W., Valsami-Jones E. \& Lead J. R. (2014). Overview of environmental nanoscience. J. R. Lead ve E. Valsami-Jones (Eds.), Frontiers of nanoscience içinde (s. 1-54). Waltham: Elsevier.

Babaii, E., Atai, M. R. ve Saidi, M. (2017). Are scientists objective? An investigation of appraisal resources in English popular science articles. Iranian Journal of Language Teaching Research. 5(1), 1-19.

Bhushan, B. (2010). Introduction to nanotechnology. B. Bhushan (Ed.), Springer handbook of nanotechnology (3nd Edition) içinde (s. 1-13). Berlin, Heidelberg: Springer-Verlag.

Bhushan, B. (2015). Governance, policy, and legislation of nanotechnology : A perspective. Microsystem Technologies, 21, 1137-1155. DOI: 10.1007/s00542-015-2511-x

Boholm, A. ve Larsson, S. (2019). What is the problem? A literature review on challenges facing the communication of nanotechnology to the public. Journal of Nanoparticle Research, 21(4). DOI: 10.1007/s11051-019-4524-3

Chang, R. P. H. (2006). Call for nanoscience education. Nanotoday. 1(2), 6-7.

Cobb, M. D. ve Macoubrie, J. (2004). Public perceptions about nanotechnology: Risks, benefits and trust. Journal of Nanoparticle Research, 6(4), 395-405. DOI: 10.1007/s11051-004-3394-4

Çıracı, S. (2007). UNAM-Malzeme bilimi ve nanoteknoloji enstitüsü: Nanobilim ve nanoteknolojide Türkiye'nin bir mükemmeliyet merkezi. http://www.mfa.gov.tr/unam_-malzeme-bilimi-ve-nanoteknoloji-enstitusu_-nanobilim-ve-nanoteknolojideturkiye_nin-bir-mukemmeliyet-merkezi-.tr.mfa adresinden alınmıştır. 
Dağtaş, E. ve Yıldız, M. E. (2015). Türkiye'de popüler bilim dergilerinin eleştirel ekonomi politik çözümlemesi: "Bilim ve Teknik" ile "Popular Science" örnekleri. Akdeniz Üniversitesi İletişim Fakültesi Dergisi, 24, 56-86.

Davis, R. (2011). A computer-aided affective content analysis of nanotechnology newspaper articles. NanoEthics, 5(3), 319-334. DOI: 10.1007/s11569-011-0129-8

Dedeoğlu, H., Şahin, A. E., Ulusoy, M. ve Ertem, İ. S. (2011). Çocuk dergileri üzerine bir içerik analizi: Bilim Çocuk ve National Geographic Kids. Akdeniz Ĕ̆itim Araştırmaları Dergisi, 9, 27-38.

Devlet Planlama Teşkilatı (DPT). (2006). Dokuzuncu kalkınma planı (2007-2013). http://www.sbb.gov.tr/wp-content/uploads/2018/11/Dokuzuncu-Kalkınma-Planı-20072013.pdf adresinden alınmıştır.

Ekli, E. (2010). İlköğretim ikinci kademe öğrencilerinin nanoteknoloji hakkındaki temel bilgi ve görüşleri ile teknolojiye yönelik tutumlarının bazı değişkenler açısından araştırılması. Yayınlanmamış yüksek lisans tezi, Muğla Üniversitesi Eğitim Bilimleri Enstitüsü, Muğla.

Erkoç, Ş. (2012). Nanobilim ve nanoteknoloji. Ankara: ODTÜ Yayıncılık.

Eroğlu, B. ve Sağlam, H. İ. (2019). Popüler bilim kitapları etkili bir öğretim aracı olarak kullanılabilir mi? Cumhuriyet Uluslararası Ĕ̆itim Dergisi, 9(3), 656-678.

Farshchi, P., Sadrnezhaad, S. K., Nejad, N. M., Mahmoodi, M. ve Ibrahimi Ghavam Abadi, L. (2011). Nanotechnology in the public eye: The case of Iran, as a developing country. Journal of Nanoparticle Research, 13(8), 3511-3519. DOI: 10.1007/s11051-011-0274-6

Fraenkel, J. R. ve Wallen, N. E. (2009). How to design and evaluate research in education. New York: McGraw-Hill.

Groboljsek, B. ve Mali, F. (2012). Daily newspapers' views on nanotechnology in. Science Communication, 34(1), 30-56. DOI: 10.1177/1075547011427974

Guenther, L. ve Ruhrmann, G. (2013). Science journalists' selection criteria and depiction of nanotechnology in German media. Journal of Science Communication, 12(3), 1-17. DOI: $10.22323 / 2.12030201$

Güner, B. ve Çitçi, M. D. (2010). Popüler bilim anlayışı ve coğrafyanın popülerliği Bilim ve Teknik Dergisi örneği. Doğu Coğrafya Dergisi, 15(24), 131-155.

Güzeloğlu, E. (2015). Akıllı ürünleriyle nano yeniliği: Gençlerin nanoteknoloji farkındalığ1, fayda/risk algiları. International Journal of Human Sciences, 12(1), 274-297.

Haslinger, J. ve Hocke, P. (2009). Nanotechnology in the media daily newspapers in Austria, Germany of nanotechnology. Institute of Technology Assessment of the Austrian Academy of Sciences, 37, 1-5. 
Hingant, B. ve Albe, V. (2010). Nanosciences and nanotechnologies learning and teaching in secondary education: A review of literature. Studies in Science Education, 46(2), 121-152. DOI: $10.1080 / 03057267.2010 .504543$

International Risk Governance Council (IRGC). (2006). White paper on risk governance, Switzerland: Geneva. https://irgc.org/wpcontent/uploads/2018/09/IRGC_white_paper_2_PDF_final_version-2.pdf adresinden alınmıştır.

Kahan D. M., Slovic P., Braman D., Gastil J. ve Cohen G. L. (2007). Affect, values, and nanotechnology risk perceptions: An experimental investigation. http://papers.ssrn.com/sol3/papers.cfm?abstract_id=968652 adresinden alınmıştır.

Kalkınma Bakanlığı (2013). Onuncu kalkınma planı (2014-2018). http://www.sbb.gov.tr/wpcontent/uploads/2018/11/Onuncu-Kalkınma-Planı-2014-2018.pdf adresinden alınmıştır.

Kamanlığlu, E. B. ve Güzeloğlu, C. (2010). Frames about nanotechnology agenda in Turkish media, 2005-2009. International Journal of Social, Management, Economics and Business Engineering, 4(4), 59-66. DOI: 10.5281/zenodo.1060593

Havadis (2018). TÜBİTAK bilim dergileri ekibi ALKÜ’ydi. https://www.havadis.web.tr/tubitak-bilim-dergileri-ekibi-alkuydi/ $\quad$ adresinden alınmıştır.

Kılıç, O. (2009). Çeviri yoluyla popüler bilim: TÜBİTAK yayınları örneğinde Türkiye'de popüler bilim alanında çeviri yaklaşımları ve sorunları. Yayınlanmamış yüksek lisans tezi, İstanbul Üniversitesi Sosyal Bilimler Enstitüsü, İstanbul.

Kılınç Alpat, S., Uyulgan, M. A., Şeker, S., Altaş, H. Ş. ve Gezer, E. (2017). Nanoteknoloji konusunda işbirlikli öğrenme yönteminin ortaöğretim 10. sınıf öğrencilerinin akademik başar1 ve görüşlerine etkisi. İnönü Üniversitesi Eğitim Fakültesi Dergisi, 18(1), 27-57.

Kjærgaard, R. S. (2010). Making a small country count: nanotechnology in Danish newspapers from 1996 to 2006. Public Understanding of Science, 19(1), 80-97. DOI: $10.1177 / 0963662508093090$

Lewenstein, B. V., Gorss, J. ve Radin, J. (2009). The salience of small: Nanotechnology coverage in the American press, 1986-2004. International Communication Association for conference'ta sunuldu, New York.

Lu K. (2009). A study of engineering freshmen regarding nanotechnology understanding. Journal of STEM Education, 10(1-2), 7-16.

Macoubrie, J. (2006). Nanotechnology: public concerns, reasoning and trust in government. Public Understanding of Science, 15(2), 221-241. DOI: 10.1177/0963662506056993

Marshall, C. ve Rossman, G. B. (1999). Designing qualitative research. London: Sage Publications. 
Metag, J. ve Marcinkowski, F. (2014). Technophobia towards emerging technologies? A comparative analysis of the media coverage of nanotechnology in Austria, Switzerland and Germany. Journalism, 15(4), 463-481. DOI: 10.1177/1464884913491045

Miles, M. B. ve Huberman, A. M. (1994). Qualitative data analysis. Thousand Oaks, CA: Sage.

$\mathrm{Ng}, \mathrm{W}$. (2009). Nanoscience and nanotechnology for the middle years. Teaching Science, 55(2), $16-24$.

Özsevgeç, T., Eroğlu, B. ve Öztürk Köroğlu, Y. (2017). Popüler bilim dergilerinin değerlendirilmesi: Bilim ve Teknik ve National Geographic örneklemi. Dicle Üniversitesi Ziya Gökalp Ĕ̈itim Fakültesi Dergisi, 30, 619-630.

Parkinson, J. ve Adendorff, R. (2004). The use of popular science articles in teaching scientific literacy. English for Specific Purposes, 23(4), 379-396. DOI: 10.1016/j.esp.2003.11.005

Patton, M. Q. (2002). Qualitative research and evaluation methods. California: Sage Publications, Thousand Oaks.

Pembegül, B. N. (2019). Tübitak tarafindan çocuklara yönelik yayımlanan popüler bilim dergilerinin çocuk hakları açısından incelenmesi. Yayınlanmamış yüksek lisans tezi, Hacettepe Üniversitesi Sağlık Bilimleri Enstitüsü, Ankara.

Pramling, N. ve Säljö, R. (2007). Scientific knowledge, popularisation, and the use of metaphors: Modern genetics in popular science magazines. Scandinavian Journal of Educational Research, 51(3), 275-295. DOI: 10.1080/00313830701356133

Sagun Gököz, B. ve Akaygün, S. (2014). Üniversiteden liseye uzanan köprü: Bir nanobilim atölye çalışması. Boğaziçi Üniversitesi Ĕ̆itim Dergisi, 31(2), 49-72.

Scheufele D. A. ve Lewenstein B. V. (2005). The public and nanotechnology: How citizens make sense of emerging technologies. Journal of Nanoparticle Research, 7, 659-667. DOI: 10.1007/s11051-005-7526-2

Sebastian, V. ve Gimenez, M. (2016). Teaching nanoscience and thinking nano at the macroscale: Nanocapsules of wisdom. Procedia - Social and Behavioral Sciences, 228, 489495. DOI: 10.1016/j.sbspro.2016.07.075

Şenel Zor, T. (2017). Etkinlik temelli nanobilim ve nanoteknoloji eğitiminin fen bilimleri öğretmen adaylarının nanobilim ve nanoteknoloji farkındalıklarına ve kavramsal anlayışlarına etkisi. Yayınlanmamış yüksek lisans tezi, Necmettin Erbakan Üniversitesi Eğitim Bilimleri Enstitüsü, Konya.

Şenel Zor, T. ve Aslan, O. (2018). The effect of activity-based nanoscience and nanotechnology education on pre-service science teachers' conceptual understanding. Journal of Nanoparticle Research, 20(75). DOI: 10.1007/s11051-018-4182-x

Senocak, E. (2014). A survey on nanotechnology in the view of the Turkish public. Science, Technology and Society, 19(1), 79-94. DOI: 10.1177/0971721813514265 
Şenocak, E. (2017). A framing theory-based content analysis of a Turkish newspaper's coverage of nanotechnology. Journal of Nanoparticle Research, 19(255). DOI: 10.1007/s11051-017-3955-y

Singh, N. A. (2017). Nanotechnology innovations, industrial applications and patents. Environmental Chemistry Letters, 15(2), 185-191. DOI: 10.1007/s10311-017-0612-8

Soltani, A. M., Tabatabaeian, S. H., Hanafizadeh, P. ve Soofi, J. B. (2011). An evaluation scheme for nanotechnology policies. Journal of Nanoparticle Research, 13, 7303-7312. DOI: 10.1007/s11051-011-0584-8

Stephens, L. F. (2005). News narratives about nano S\&T in major U.S. and non-U.S. newspapers. Science Communication, 27(2), 175-199. DOI: 10.1177/1075547005281520

T.C. Bilim Sanayi ve Teknoloji Bakanlı̆̆ı (BSTB). (2017). Türkiye nanoteknoloj stratejisi ve eylem planı (2017-2018). https://www.gmka.gov.tr/dokumanlar/yayinlar/20172018_Nanoteknoloji-Stratejisi-ve-Eylem-Plani.pdf adresinden alınmıştır.

Tseronis, A. (2018). The explicit/implicit distinction in multimodal argumentation: comparing the argumentative use of nano-images in scientific journals and science magazines. $\mathrm{S}$. Oswald ve D. Maillat (Eds.), Argumentation and inference: Proceedings of the 2 nd European conference on argumentation içinde (s. 821-842). London: College Publications.

Tunçel M., Vuran Doğan Ö. ve Ardıç Çobaner A. (2012). Performans sistemine medyanın bakışını anlamak: performans konulu sağlık haberleri üzerine bir araştırma, Sağlıkta Performans ve Kalite Dergisi, 3, 93-118.

TÜBITTAK Ulusal Gözlemevi (TUG). (2020). Popüler bilim dergileri. https://tug.tubitak.gov.tr/tr/populer-bilim-dergileri-1 adresinden alınmıştır.

Türk Sanayicileri ve İşadamları Derneği (TÜSİAD). (2008). Uluslararası rekabet stratejileri: nanoteknoloji ve Türkiye. https:/tusiad.org/tr/yayinlar/raporlar/item/9000-uluslararasirekabet-stratejileri-nanoteknoloji-ve-turkiye adresinden alınmıştır.

Türkiye Bilimsel ve Teknolojik Araştırma Kurumu (TÜBİTAK). (t.y.). Popüler bilim yazarları için el kitabı. http://docplayer.biz.tr/2719110-Bilim-teknik-populer-bilim-yazarlari-icinel-kitabi.html adresinden alınmıştır.

Türkiye Bilimsel ve Teknolojik Araştırma Kurumu (TÜBİTAK). (2004). Ulusal bilim ve teknoloji politikalar1-vizyon 2003-2023 strateji belgesi. https://www.tubitak.gov.tr/tubitak_content_files/vizyon2023/Vizyon2023_Strateji_Belg esi.pdf adresinden alınmıştır.

Türkiye Bilimsel ve Teknolojik Araştırma Kurumu (TÜBİTAK). (2009). Bülten (Sayı 92). https://www.tubitak.gov.tr/sites/default/files/content_files/iletisim/edergi/92.pdfhttps:/ /www.tubitak.gov.tr/sites/default/files/content_files/iletisim/edergi/92.pdf adresinden alınmıştır. 
Türkiye Bilimsel ve Teknolojik Araştırma Kurumu (TÜBİTAK). (2020a). 2020 yılı performans programı. https://tubitak.gov.tr/sites/default/files/18842/2020-pp.pdf adresinden alınmıştır.

Türkiye Bilimsel ve Teknolojik Araştırma Kurumu (TÜBİTAK). (2020b). TÜBİTAK tarihçesi. https://www.tubitak.gov.tr/tr/icerik-hakkimizda adresinden alınmıştır.

Türkiye Bilimsel ve Teknolojik Araştırma Kurumu (TÜBİTAK). (2020c). Popüler bilim dergileri. https://www.tubitak.gov.tr/tr/yayinlar/icerik-populer-bilim-dergileri adresinden alınmıştır.

Türkiye Cumhuriyeti Cumhurbaşkanlığ1 Strateji ve Bütçe Başkanlığ1. (2019). On birinci kalkınma planı (2019-2023). http://www.sbb.gov.tr/kalkinma-planlari/ adresinden alınmıştır.

Ucer, S. (2019). Fen öğretiminde popüler bilim makalelerinin rolü: atom kavramı örneği. Yayınlanmamış yüksek lisans tezi, Aksaray Üniversitesi Fen Bilimleri Enstitüsü, Aksaray.

Ulusal Nanoteknoloji Araştırma Merkezi Malzeme Bilimi ve Araştırma Enstitüsü. (2013). 2013 faaliyet raporu. http://unam.bilkent.edu.tr/docs/UNAM_AR2013TR.pdf adresinden alınmıştır.

Utma, S. (2015). Bilim iletişimi ve bilim gazeteciliği: ege üniversitesi haber ajansı örneğinde üniversitelerde bilim haberlerinin üretilmesine yönelik bir inceleme. Yayınlanmamış doktora tezi, Ege Üniversitesi Sosyal Bilimler Enstitüsü, İzmir.

Weaver, D. A., Lively, E. ve Bimber, B. (2009). Searching for a frame: news media tell the ttory of technological progress, risk, and regulation. Science Communication, 31(2), 139-166. DOI: $10.1177 / 1075547009340345$

Yavuz, M. ve Balkan Kıyıc1, F. (2012). Popüler bilim dergileri ve bilimsel kitapların fen derslerinde kullanılma durumları. 3rd International Science, Technology and Engineering Conference (ISTEC)'te sunulmuş. Dubai.

Yavuzoğlu, Ç. (2018). Süreli çocuk yayınlarının fen bilimleri eğitimi bağlamında bilim tarihi açısından incelenmesi. Yayınlanmamış yüksek lisans tezi, Kastamonu Üniversitesi Fen Bilimleri Enstitüsü, Kastamonu.

Yazır, Ü. (2018). Biyoloji eğitiminde bir eğitim materyali olarak popüler bilim dergilerinin öğrencilerin bilime ve biyoloji dersine yönelik tutumlarına etkisi. Yayınlanmamış yüksek lisans tezi, Gazi Üniversitesi Eğitim Bilimleri Entitüsü, Ankara.

Yenikurtuluş, H. (2007). Üniversite kütüphanelerinde elektronik bilgi kaynaklarına dayal yararlandırma hizmeti: İstanbul bilgi üniversitesi kütüphanesi uygulama örneği. Yayınlanmamış yüksek lisans tezi, İstanbul Üniversitesi Sosyal Bilimler Enstitüsü, İstanbul. 
Yeter, F. (2019). Çocuk dergilerinin sosyal bilgiler öğretim programındaki değerler açısından incelenmesi. Yayınlanmamış yüksek lisans tezi, Afyon Kocatepe Üniversitesi Sosyal Bilimler Enstitüsü, Afyonkarahisar. 